\title{
Methodological issues of metrological analysis of planned medieval towns and villages
}

\author{
Maria Legut-Pintal ${ }^{1}$, Anna Kubicka ${ }^{2}$ \\ ${ }^{1}$ University of Wrocław, Institute of Archaeology, ul. Szewska 48, 50-137 Wrocław, Poland \\ 2 Warsaw University of Technology, Department of Geodesy and Cartography, Plac Politechniki 1, 00-661 Warszawa, Poland
}

\begin{abstract}
In this paper, we illustrate problems related to the application of two methods used for the reconstruction of the parcellation of medieval towns: modular analysis and the cosine quantogram. We propose the usage of the cosine quantogram, which is rarely used to study urban layout, for the identification of units of measurement in regular medieval towns. Based on two examples from the region of Silesia, Poland, Namysłów and Dzierżoniów, we discuss the usefulness of both methods in the reconstruction of the original measuring system and town layout. For the first time, we have applied these two methods to the study of the layout of a regular village. Despite the limitations, such as the level of precision in the construction of a medieval town's layout at the time of its foundation, later changes to the division of plots and the known inaccuracy of modern maps, it seems that combining both methods allows the determination of the module used for the planning of the original urban layout. The application of the cosine quantogram can be useful for improving the results of modular analysis. Nevertheless, the results of both methods should be verified against archaeological results and historical research.
\end{abstract}

\section{Section: RESEARCH PAPER}

Keywords: modular analysis; unit of measurement; Lower Silesia; parcellation; cosine quantogram

Citation: Anna Maria Kubicka, Maria Legut-Pintal, Methodological issues of metrological analysis of planned medieval towns and villages, Acta IMEKO, vol. 10, no. 1, article 29, March 2021, identifier: IMEKO-ACTA-10 (2021)-01-29

Editor: Ioan Tudosa, University of Sannio, Italy

Received May 15, 2020; In final form November 13, 2020; Published March 2021

Copyright: This is an open-access article distributed under the terms of the Creative Commons Attribution 3.0 License, which permits unrestricted use, distribution, and reproduction in any medium, provided the original author and source are credited.

Funding: The paper presents the preliminary results of a project funded by the Polish National Science Centre, No. 2020/39/D/HS3/01549.

Corresponding author: Maria Legut-Pintal, e-mail: maria.legut-pintal@uwr.edu.pl

\section{INTRODUCTION}

Imagine you are a surveyor, hired to plan a new town in the middle of nowhere using only a rope and a stick. Is it possible that the effects of your work will still be visible after hundreds of years?

The issue of surveying and dividing the area inside the walls of a medieval town has been the subject of academic debate [1][4]. Research on the reconstruction of the primary layout of medieval towns in Central Europe has a long tradition [5]-[7]. This debate has mainly been stimulated by historians, architects and urban planners; however, a few archaeologists have also influenced the discussion. Central Europe from the 12th to the 16th century was a place of urban and rural revolution. As a result of colonisation, hundreds of towns and thousands of villages were newly established. The 'regular' town was a result of the implementation of German law on spatial dimensions [8]. Towns with market squares and an orthogonal grid of streets appeared at the beginning of the 13th Century in Silesia, a region in today's Poland. These Silesian towns had a regular gridded urban pattern, which made them very distinct in the cultural setting of Central Europe. Urban pattern analysis, using the modular method, has been conducted for numerous Silesian towns. These studies have resulted in a better understanding of the medieval cityscape; for example, the exact sizes of primary plots have been estimated. During this period, some improvements in the layout of towns were made. The main observed tendency was that, in the 13th century, the city grid was 'optimised'. The layout of the town centre evolved from a wide market street to a rectangular or square market - the width of the plot decreased, the blocks of buildings were shortened, and the size and proportions of market squares became standardised [9]. The developed model of a Silesian regular town spread further, to be used in neighbouring lands.

In addition, the findings of archaeological excavations have extended the knowledge of the planning of medieval towns [10], [11]. It is worth noting that, in many cases, archaeological 
discoveries have confirmed the theoretical consideration of metrological analysis.

Metrological analyses related to urban and rural planning are based on the assumption that in the case of regular settlements founded on previously uninhabited areas (lat. in cruda radice), the arranged space was specified in the contract between the locator and the founder (territorial lord - king, duke, knight, bishop, etc.); the area, the number of plots and their sizes were measured in the field applying algorithms. Despite subsequent changes, in many cases, in the division of plots and their development, it is possible to reconstruct the original 'ideal' plan. Decoding the original intention of the planner is the starting point for analysing subsequent changes in urban or rural space and studying their causes.

In this paper, we will discuss the potential of metrological methods and their limitations in the study of regular towns and villages based on selected examples from the Silesian region. We aim to address the following questions: were medieval towns planned with mathematical precision? And if so, is it possible after all these years, to reconstruct the idea of medieval urban planning based on modern cadastral plans and terrain surveys? Is it then possible to apply the methodology of urban analysis to regular villages?

\section{METHODS}

In this paper we combine two methods of analysis, the modular analysis of a town layout and the cosine quantogram algorithm, which are applied to a series of measurements of a town. These methods represent two different approaches. In the first, the base unit of measurement is considered as known, from written sources, for example, and is well established. In the second method, the base unit is unknown and determined using statistical methods.

\subsection{Modular analysis}

The method used for the spatial analysis of an historic town's plan consists of applying information from historical, iconographic, archaeological and architectural sources to the modern geodetic plan to reconstruct the transformation of the original city morphology [12]. This approach also includes the use of metrological methods.

Modular analysis or the meteorological-geometric analysis method assumes the existence of a module that can be found in the city structure (e.g. dimensions of the market square and blocks of buildings or the width of streets). Among the lengths of measurement of basic objects in a town's plan, a pattern of 'round' multiplications $(50,100,150)$ of the base-unit (foot) length is sought to establish which measurement system was used by medieval surveyors for planning. Having established a base measurement system, the whole plan is fitted into a rope-length grid, recalculating the lengths according to the multiplication of the rope lengths.

However, grid adjustments are heavily burdened with errors in approximations related to the irregularity of the city and the fact that the original starting point from which it was measured is unknown. It is uncertain whether rope-length grid was commonly used as a too. While in some cases the rope-length grid was certainly used to determine the city's area and mark out the market square, in other cases the determination of the main axes of the town might have be sufficient.

To reconstruct the original width of urban plots, a simple method is used. It consists of summing up the length of facades of neighbouring plots converted to the basic foot unit. Its advantage is in enabling the partial elimination of border shifts between neighbours resulting, for instance, from the possibility of erecting a firewall on the neighbour's plot or hereditary divisions. However, the main problem is often an arbitrary determination of the size of the basic unit.

The modular analysis method has been widely criticised for its susceptibility to errors resulting from inaccurate measurements made on historical plans and a dependence on the arbitrarily selected basic length unit. Thanks to new methods of analysis, in particular the possibility of measuring using geodetic ground plans or the use of GIS software to apply information from various sources, the modular analysis method has returned to favour. Nevertheless, the allegation that the underlying units of measurement are arbitrary has still not been resolved.

\subsection{Cosine quantogram}

The cosine quantogram is a method for reconstructing the smallest basic unit used in the design and construction process. The cosine quantogram algorithm was developed by D. G. Kendall to detect a quantum of unknown size from a set of data [13]. A statistical model of a cosine quantogram has successfully been implemented for the analysis of architectural sites of Mediterranean culture, studies on the layout of early medieval Anglo-Saxon settlements [14] and even in the meteorological analysis of architectural units in the Incan architecture of Machu Picchu [15]. Known examples of the method's use suggest that it could also be applied to the analyses of medieval regular cities.

In the case of medieval town planning, a data set for metrological analysis is composed of parcel dimensions. Each parcel dimension can be described as an integer $M$, multiplied by the basic unit $q$ plus an error $\varepsilon$ (epsilon); the error might be the result of inaccuracy in the layout of the medieval city as well as modern methods of measurement:

$$
X_{i}=M_{i} q+\varepsilon_{i} \text {. }
$$

In the equation, $\varepsilon$, which is significantly smaller than $q$, is analysed and then the formula is applied to calculate an amount that clusters around $q(2)$. The value of $q$, which maximises the formula within a given range, is the one with the highest probability of being a quantum:

$$
f(q)=\sqrt{\frac{2}{N}} \cdot \sum_{i=1}^{n} \cos \left(\frac{2 \pi \varepsilon_{i}}{q}\right)
$$

where $N$ is the sample size and the set of building dimensions. The term $\sqrt{2 / N}$ adds the dependence of the cosine quantogram result to the sample size. The main problem of the application of the cosine quantogram to urban studies is the small size of the sample. We can usually obtain only a dozen, sometimes a few dozen, measurements. To ensure that the estimated quantum is neither evaluated by chance nor dominated by outlier measurements, we have applied the Monte Carlo bootstrap method, used to construct confidence intervals, to estimate the most likely quantum value range. Assuming a 5\% significance level, if the quantum estimation for the original data falls within the confidence interval, the risk that the quantum is the product of chance can be interpreted as very low.

\section{CASE STUDIES}

For an evaluation of the described methods, we selected two regular towns from Silesia, Namysłów and Dzierżoniów, 
founded in the advanced phase of colonisation. Both towns were founded in cruda radice, so no previous settlements affected their shape. In both towns, architectural and archaeological excavation confirmed the existence of medieval masonry from buildings, whose presence can provide information on the position of medieval plot boundaries.

To check whether the methods used for town studies can also be applied to village research, we chose for our analysis one of the most regular Silesian villages, Mnichowice. The main question was, if the boundaries between the plots had never been fixed by walls, but only by wooden fences, would it be possible to decipher the original division units?

\subsection{Namysłów}

Namysłów was founded, according to written sources, around 1250 [16]. The layout of the town is quite well preserved. Small changes to block layouts are connected with the existence of wooden construction and arcades around the market square as well as the introduction of some new developments after the damage caused by World War II. Nevertheless, the northern frontage of the market square was fully built from bricks in the $14^{\text {th }}-15^{\text {th }}$ century, which froze the medieval boundaries of plots. This allows the measurements determined using the cadastral plans of the town in the field and their accuracy to be verified by measuring the façades of the tenement houses.

First, we verified the results of previous studies on Namysłów parcellation [15]. The quantum was estimated based on the series of archive data on plot dimensions that had previously been analysed using the neighbouring plot method. The cosine quantogram function provides clear results in relation to the estimated quantum from the archive data set, $0.25 \mathrm{~m}$ (Figure 1a), which does not match the results of the neighbouring plot method, proposed by [17], in which the module of $0.31 \mathrm{~m}$ was re-established in the urban reconstruction of Namysłów. This first step in the study of Namysłów reveals that the two different methods of measurement analysis of the same data achieve two different results. Therefore, in the next step of the module search in relation to regular town planning, we applied cosine quantogram analysis to the set of measurements collected for this study in the field from Namysłów's main square.

The estimated value of the quantum from 16 field measurements was $0.155 \mathrm{~m}$ (Figure 1b), which is half of the foot standard established from written sources - $0.313 \mathrm{~m}$, the socalled Renish foot. The maximum of the function shows the smallest unit present in the set of measurements; therefore, we should interpret the Renish foot standard as the module used in Namysłów's medieval parcellation of tenant houses in the main square.

The final results of both methods of measurement analysis showed the same results in the search for modules in Namysłów's main square. However, the results of the first method could not be confirmed by the second method, the cosine quantogram. The difference in results from the same data was influenced by the accuracy to which the actual measurement values were rounded, which made it impossible to obtain the same results with different methods. Nevertheless, the application of the cosine quantogram proved that, in the case of Namysłów's buildings, the division of the medieval plot is still preserved.

In the second step, with an already confirmed unit of measurement, the $0.31 \mathrm{~m}$ Renish foot, we applied modular analysis to the town's plan (Figure 2). We built the modular grids based on three different units used in medieval Poland: $44.5 \mathrm{~m}$, based on a $0.296 \mathrm{~m}$ foot (green lines); $43.2 \mathrm{~m}$, based on a foot of

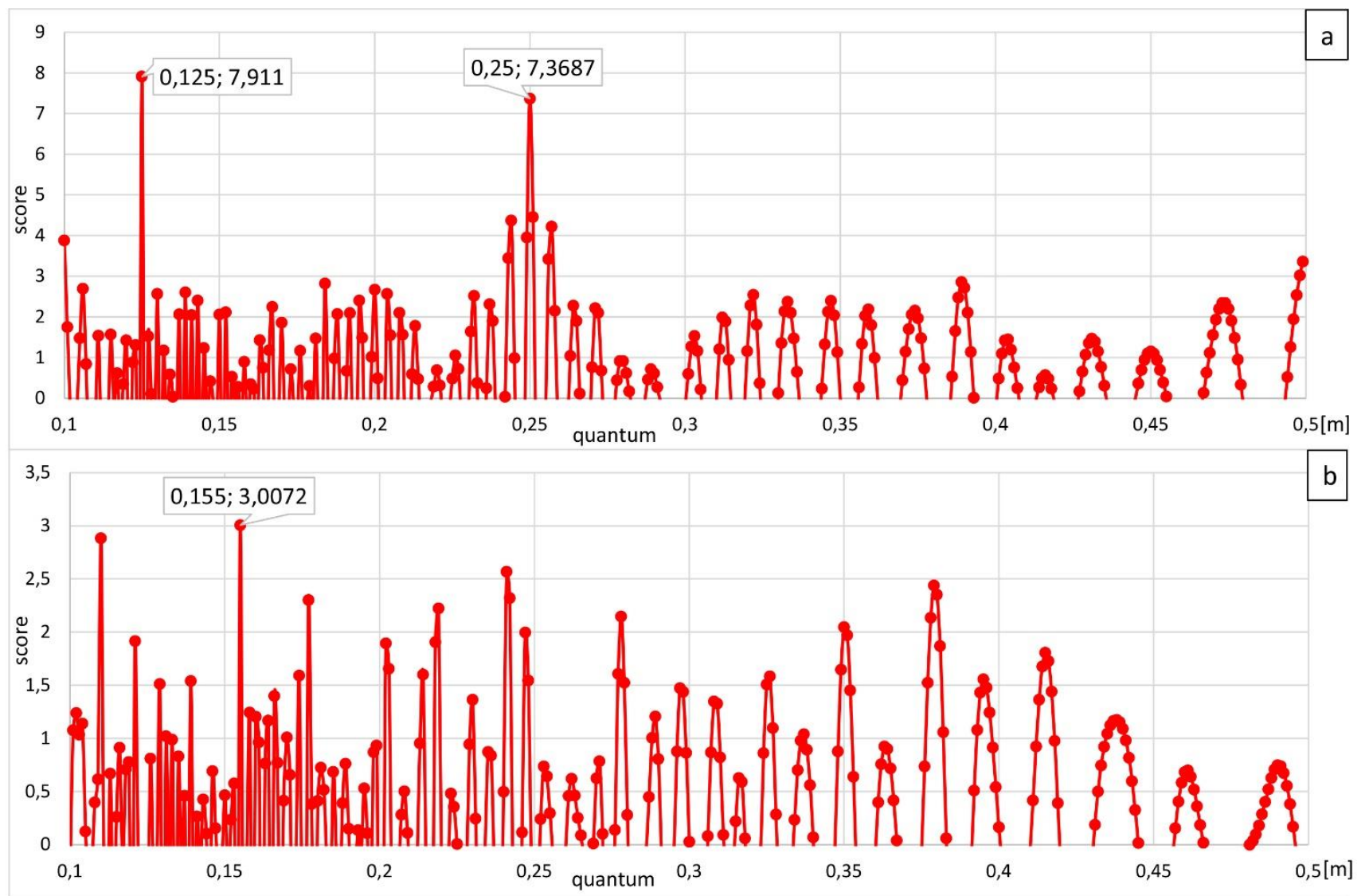

Figure 1. a) Quantum estimation from the archive data set for Namysłów; b) Quantum estimation from the data set collected during a field survey in Namysłów. 




Figure 2. Namysłów: matching different grid sizes to the town plan. Green lines - module $44.5 \mathrm{~m}$, blues lines - module $43.2 \mathrm{~m}$, red lines - module $46.5 \mathrm{~m}$, red dots - location of town gates.

$0.288 \mathrm{~m}$ (Kulm/Flemish foot; blue lines); and $46.5 \mathrm{~m}$, based on a foot of $0.31 \mathrm{~m}$ (Renish foot, red lines). We then compared the results. The third step was to fit a grid to the crucial elements of the medieval town. Our reference for fitting the grid included the location and orientation of the most important elements of the town, such as the main frontage of the blocks (the west frontage) and the very well-preserved north frontage of the main square. The grid borders should finish within the line of fortification and be adjusted to the main elements of the town. The differences between the matching of the individual grids were not large, and it was possible to say that most elements from the preserved layout of the city fit into a rope grid with a side of $46.5 \mathrm{~m}$ (foot of $0.31 \mathrm{~m}$ ). Using the standard unit of the Renish foot, the market has dimensions of $3 \times 1.5$ ropes, and the area of the whole regularly planned town probably fit into a grid $6 \times 9$ ropes.

The results from applying three different methods of town planning analysis demonstrate the uniformity of the urban space in which the same unit of measurement (the Renish foot) was used to divide housing and plan the grid of the whole medieval town. However, the internal divisions of the blocks seem to be independent of the rope grid, which marks the main elements and the city border.

\subsection{Dzierżoniów}

The founding of Dzierżoniów (ger. Reichenbach), took place around 1260 [17]. The organisation of the city centre is based on the model of a cross, with a centrally located market square and streets intersecting in the centre. The course of the walls surrounding the city is almost round.

As with the previous case, we started the analysis of Dzierżoniów's plan with a metrological analysis of block parcellation. In this case, there are no similar studies with which to compare the results. The data set for the parcellation measurement came from the cadastral plans of the eastern wing of the market square. However, archaeological surveys conducted on the eastern block document the significant transformation of the earlier buildings. For this reason, we used a reconstruction of the width of each parcel for analysis, which is still visible in the modern town plan. The reconstruction of the potential medieval plot division is based on the results of the modular analysis and archaeological survey as well as an analysis of the preserved boundaries. We verified the existence of a potential quantum in a reconstructed model of the town (without later divisions of plots). The maximum value of the quantum was $0.272 \mathrm{~m}$ (Figure 3). The bootstrap simulation also confirmed the

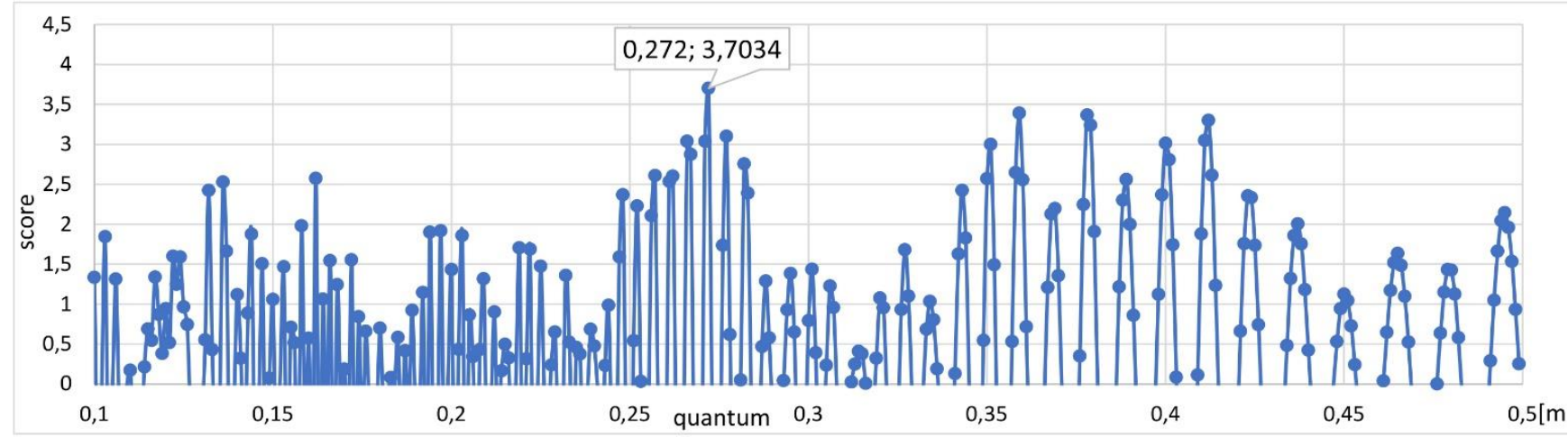

Figure 3. Quantum estimation for Dzierżoniów's data. Data set was based on a reconstructed plot division of the eastern frontage. 




Figure 4. Dzierżoniów: the bootstrap confidence interval for the quantum is $0.272 \mathrm{~m}$.

results of $0.272 \mathrm{~m}$ as the best candidate for the basic unit of measurement (Figure 4).

However, the value differed from that expected by $0.016 \mathrm{~m}$.

This error does not seem large if we consider that the measurements were taken from a plan with an accuracy of about $0.10 \mathrm{~m}$ on the plot borders. Even if the quantum value obtained as a result of the distorted measurements is not identical to that expected, the quantum can be considered an indication of the unit used at a specific time period. In this example, the value of the quantum of $0.272 \mathrm{~m}$ is closer to the Polish foot $(0.288 \mathrm{~m})$ than the Renish $(0.313 \mathrm{~m})$. We presume that more precise measurements made in the field can bring the quantum value closer to the original unit of measurement.

In the second step in the study of medieval town planning based on modular analysis and calculating the width of neighbouring plots, we tried fitting the rope-length grids into the town plan, in the same way as with Namysłów (Figure 5).
The most regular part of the town was the market, with dimensions of around $2 \times 3$ ropes. Although the western and eastern fronts fit into the grid well, the southern and northern frontages did not. Seemingly regular streets appeared to diverge after the imposition of the grid, which is to a certain extent the result of uneven terrain and the town's location on a hill. It seems that the area of the medieval town fit into a square of $10 \times 10$ ropes. The most probable rope length used was that of $43.2 \mathrm{~m}$ (blue lines), which corresponds to a foot of $0.288 \mathrm{~m}$.

\subsection{Mnichowice}

Mnichowice is a small village in the district of Bralin, in Kępno County, Greater Poland Province. This area historically belonged to Silesia. The first mention of the village dates to 1220 , at which time it was the property of the Augustinian monastery in Wrocław. The reorganisation of village according to Germanlaw is confirmed in a document from Duke Henry IV dated 25 February 1276, and it is probably after this date that the village was transformed into a regular Angerdorf shape. The Angerdorftype villages, with oblong village greens and two rectangular blocks of farmsteads on either side, are typical for German-law villages in the lowlands, especially in Saxony, Silesia, Bohemia and Pomerania [18].

The ground plan of Mnichowice's intravilan (built-up area) is very regular, almost rectangular, and its border has been strengthened along the roads. The village green was affected by transformations in the modern period; it was partially built up, and plot owners have attached part of the square to their farmsteads. The original border of the village green has partly been preserved by the location of rural houses, which have generally been built in the same place since the Middle Ages.

The ideal concept of Mnichowice village consisted of a rectangular village green with a width of one rope (approx. 43.2 m) and two rows of farmsteads (a 2.5 rope width - approx. 106

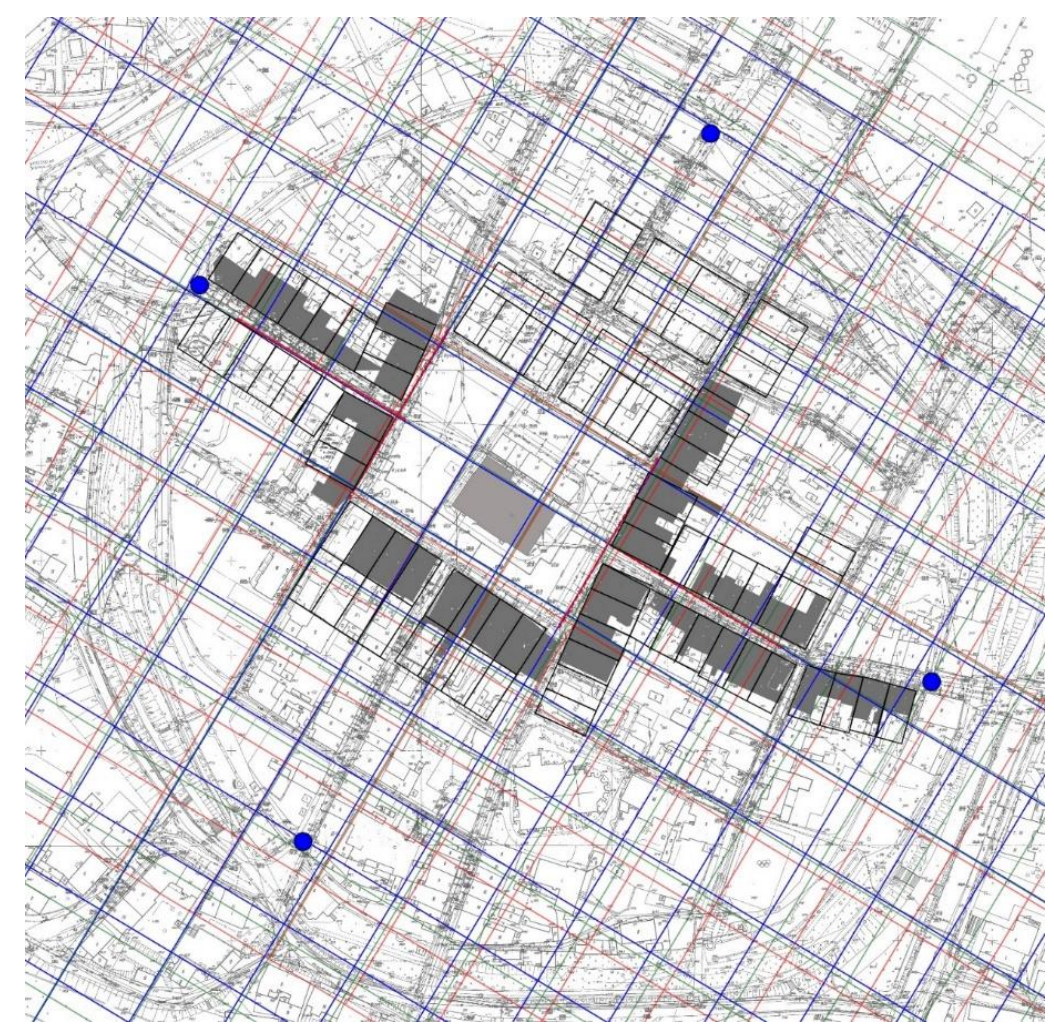

Figure 5. Dzierżoniów: matching different rope-length grids to the town plan. Green lines - module $44.5 \mathrm{~m}$, blues lines - module $43.2 \mathrm{~m}$, red lines - module 46.5 $\mathrm{m}$, blue dots - location of town gates. 


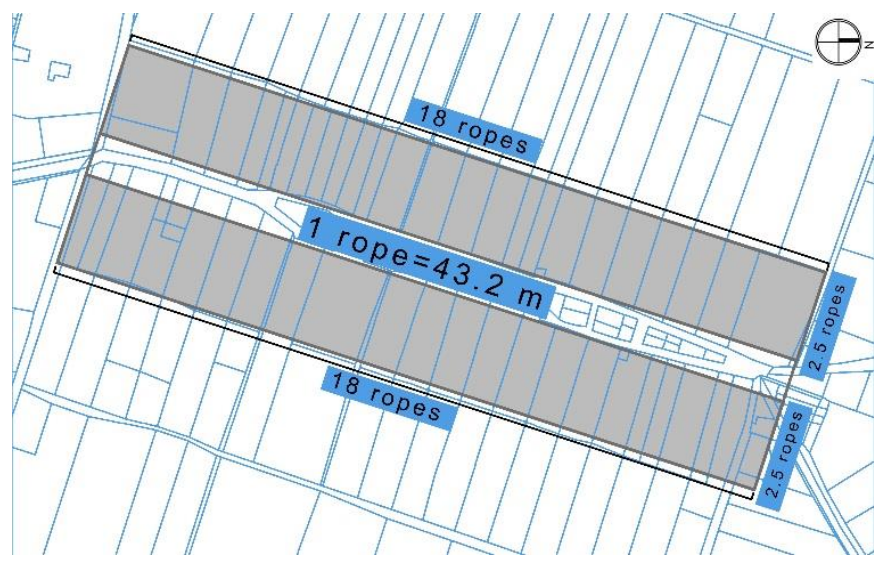

Figure 6. Mnichowice: current plot division (blue line) and reconstruction of an ideal plan of the village core (grey).

$\mathrm{m})$. The reconstructed area of the intravilan was $6 \times 18$ ropes, which is 0.75 of a lesser lan (ger. kleine Hube - an old unit of area used in lands of German colonisation). Although it is not proven that the blocks of buildings were to be divided into equal plots, it seems that in this case a certain module was used (Figure 6). The width of the plots ranged between $34 \mathrm{~m}$ and $37 \mathrm{~m}$. In one case, the width of the plot was double and was $72.59 \mathrm{~m}$.

The maximum value of the quantum from the measurements of the plot widths was $36.29 \mathrm{~m}$ (Figure 7).

On this basis, we can conclude that the division into plots was independent of the distribution of the general layout of the village, and a rope of $43.2 \mathrm{~m}$ was not used. Instead, the length of the whole intravilan was measured using a different module to plot division. For the plot division, the value of about $36 \mathrm{~m}$ was equal to the so-called 'small' rope; 125 feet was used to delineate the parcellation. Small ropes are not confirmed in written sources from Silesia, but they were in use in neighbouring Lesser Poland [19]. In order to measure the integer number of equal plots in the whole length of the village, it is necessary to find the least common multiple of both moduli. If we consider the use of two types of rope, 150 feet and 125 feet, the common multiple would be 750 feet. Mnichowice's intravilan is about 2,690 feet, and this length is not an integer multiplication of this module. This caused irregularities in plot division, visible at both ends of the village. The usage of different modules of division may also be explained by the idea that the designation of internal roads shortened the road from the centre of the village to the fields.

\section{DISCUSSION}

Studies on the reconstruction of the layout of medieval towns face many limitations related to the subject of research and the methods used.

The first group of limitations is caused by inaccuracies made at the time the settlement was founded, resulting from, for example, human error, terrain conditions and the imperfection of tools used during delineation, such as ropes and rods. Even in the most regular towns, only the central area, near the market square, is regular, and the further from the market, the more irregularities there are. This is caused by the gradual process of the building of towns, which took decades.

The second group of limitations is the result of numerous transformations in the original layout. In many cases, Central European small towns were developed primarily with wooden buildings, which did not perpetuate the original boundaries, including the arcades that occupied space in the streets or the market square. Even the early introduction of masonry buildings did not preserve the original boundaries, as the law allowed the construction of frontier walls using a neighbour's plot. Numerous distortions in the original arrangement of blocks of buildings have also been lost as a result of divisions and the linking of neighbouring plots. In addition, fortifications built even a hundred years after the town's founding usually enclosed the town within an oval border, cutting off the rope-length grid and intersecting adjacent plots.

The third group of limitations is connected with inaccuracies in the modern plans used for analysis. The accuracy of large-scale maps is about $0.10 \mathrm{~m}$. This value is rather large when we think of determining units of length of $0.27-0.35 \mathrm{~m}$. Even taking accurate measurements in the field does not guarantee that the original boundaries of the plot will be captured because the boundaries of the façades of individual objects are not the same as the plot boundary. Only in a few examples of Silesian towns are the boundaries of plots confirmed by archaeological excavation (e.g. Wrocław).

The fourth group of limitations is related to the specification of methods. One of the aims of the research is to establish relatively small differences between the basic measurements of each system of town planning. In the case of the cosine quantogram method, the main risks and disadvantages are related to having a sufficient quantity of measurements with credible values.

It is only in the towns of Silesia and Lesser Poland that known systems of measurement exist in which basic values varied. Depending on the time period, location, role and foundation of



Figure 7. Quantum estimation from the data set of block parcellation in Mnichowice village. 
the town, we can expect differences in the module value. In some cases, we have written sources in which the standard measurements were mentioned, but in the vast majority of cases, only analysis can provide information about the measurement used to plan the layout of the town.

\section{CONCLUSION}

The results presented above indicate that the application of metrological methods in urban history studies has many limitations and requires a holistic and interdisciplinary approach. Despite these limitations, it seems that the use of the cosine quantogram method in combination with traditional modular analysis may provide some new opportunities. In some cases, as in Namysłów, confirmation of the basic unit may be possible. In others, it may indicate the most likely basic unit. The example of the village of Mnichowice confirms that the cosine quantogram may also be used to establish larger modules (rope), not only small units (foot).

In further studies, we also aim to apply the methodology we have adopted to regular settlements founded in cruda radice in Western Europe, for example, in France and Italy. The appearance of stone houses there, built shortly after the founding process, should affect the stabilisation of the measured boundaries in the city structure; therefore, the results obtained in the measurement analysis should be more accurate.

\section{REFERENCES}

[1] H. Keller, Die ostdeutsche Kolonialstadt des 13. Jahrhunderts und ihre südländischen Vorbilder, F. Steiner, Wiesbaden, 1979, ISBN -10: 3515032460.

[2] W. Boerejfin, The foundation, planning and building of new towns in the 13th and 14th centuries in Europe: an architecturalhistorical research into urban form and its creation, Amsterdam Institute for Humanities Research, Amsterdam, 2010, ISBN 9789090251578.

[3] K. Humper, M. Schenk, Entdeckung der Mittelalterlichen Stadtplanung. Das Ende vom Mythos der gewachsenen Stadt, Theiss, Stuttgart, 2001, ISBN-10: 3806214646.

[4] U. Untermann, Strassen, Areae, Stadtmauern, mittelalterliche Stadtplanung im Licht der Archäologie, in: StädteplanungPlanungsstädte. B. Fritzsche, HJ. Gilomen, M. Stercken (editors). Chronos, Zürich, 2006, ISBN 10: 3034007620, pp. 39-50.

[5] T. Zagrodzki, Regularny plan miasta średniowiecznego a limitacja miernicza, Studia Wczesnosredniowieczne 5 (1962), ISSN 00817031.
[6] T. Kozaczewski, Wielkość i program budowy miasta średniowiecznego, Wydawn. Politechniki Wrocławskiej, Wrocław, 1972.

[7] J. Pudełko, Próba pomiarowej metody badania planów niektórych miast średniowiecznych w oparciu o zagadnienie działki, Kwartalnik Architektury i Urbanistyki 9 (1964) pp. 3-28.

[8] G. Köster, C. Link, Faszination Stadt: Die Urbanisierung Europas im Mittelalter und das Magdeburger Recht, Sandstein Kommunikation, Magdeburg, 2020, ISBN -10: 3954984539.

[9] R. Eysymontt, Kod genetyczny miasta. Średniowieczne miasta lokacyjne Dolnego Śląska na tle urbanistyki europejskiej, Via Nova, Wrocław, 2009, ISBN 978-83-60544-556.

[10] C. Buśko, Stan badań nad parcela mieszczańską w średniowiecznych miastach śląskich, Kwartalnik Historii Kultury Materialnej 43 (1995) pp. 343-350.

[11] J. Piekalski, Centrum średniowiecznego miasta jako problem badawczy archeologa, Wratislavia Antiqua 2 (2000) pp. 11-15.

[12] T. Zarębska, Badania historyczno-urbanistyczne metoda analiz przestrzennych, Kwartalnik Historii Kultury Materialnej 43 (1995) pp. 15-32.

[13] D. G. Kendall, Hunting quanta, Philosophical Transactions of the Royal Society of London, Series A, Mathematical and Physical Science 276 (1974) pp. 231-266.

[14] J. Blair, Modules for Anglo-Saxon constructions. Appendix to Grid-planning in Anglo-Saxon settlements: the short perch and the four-perch module, Anglo-Saxon Studies in Archaeology and History 18 (2013) pp. 55-57.

[15] A. Kubicka, The metrological research of the Machu Picchu site. Application of a cosine quantogram method for 3D laser data, ACTA IMEKO 6 (2017) 3, 52-56. DOI: $10.21014 /$ acta imeko.v6i3.460

[16] Namysłów, in: Atlas Historyczny Miast Polskich, vol. 4 Ślask nr. 11, M. Młynarska-Kaletynowa (editor). IAE PAN, Wrocław, 2015, ISBN 978-83-63760-58-8, pp. 53-59.

[17] M. M. Wańkowicz, Rola działki miejskiej w procesie lokacyjnym na przykładzie miasta Dzierżoniowa, Wiadomości Konserwatorskie 20 (2006) pp. 53-59.

[18] M. Hardt, Formen und Wege der hochmittelalterlichen Siedlungsgründung, in: Ostsiedlung und Landesausbau in Sachsen. Die Kührener Urkunde von 1154 und ihr historisches Umfeld. E. Bünz (editor). Leipzig, 2008, ISBN-10: 3865831656, pp.143-160.

[19] B. Krasnowolski, Lokacyjne układy urbanistyczne na obszarze ziemi krakowskiej w XIII i XIV wieku. Cz. 1, Miasta Ziemi Krakowskiej, chronologia procesów osadniczych i typologia układów urbanistycznych, Wydawnictwo Naukowe Akademii Pedagogicznej, Kraków, 2004, ISBN 83-7271-276-X, p. 138. 